\title{
Mensaje postrero de César Vallejo
}

$E^{\text {L renacimiento del alma griega como el triunfo del cristianismo }}$ y la caída del imperio romano en la antigüedad, son fenómenos de trascendencia universal en la vida del espíritu. El derrumbe del régimen medieval y la constitución de las agrupaciones humanas en la edad moderna, con el florecimiento de las artes a mediados del siglo $\mathrm{xv}$, señalan un gran avance en la conquista de los bienes materiales, porque dieron confianza al hombre en su valer y formaron convicciones en cuanto a su porvenir. El predominio del espíritu latino sobre la influencia islámica, ejerció una función tan decisiva en el concierto de la humanidad como el reformismo y los principios fundamentales sentados por los enciclopedistas, que al correr del tiempo ofrecen al hombre nuevos horizontes en la búsqueda del porvenir.

La caída de las monarquias europeas que dió por resultado el triunfo del sistema republicano, cambiando el concepto del absolutismo divino por el establecimiento de una conciencia democrática de base popular, elegida por cada habitante, y la delimitación de las funciones religiosas, cuyos poderes fueron separados de la actividad civil, con el nacimiento de los grandes consorcios capitalistas, que por vía del régimen de la propiedad privada establecieron nuevos campos de combate en los tiempos modernos que antes estaban reservados a los príncipes, señalan inequívocamente esa inquietud permanente del pensamiento del hombre, rebelde e insumiso frente al arcaísmo de las costumbres, formas e instituciones.

Al nacimiento del sistema capitalista como tal, sucedió en corto intervalo de años una nueva clase, la burguesía, que comprando cuanto es objeto de transacción, desde bienes patrimoniales, reales 
a industriales hasta la misma conciencia individual en venta, se lanzó al combate con todos los restos de una civilización esclava al interés. $\mathrm{Y}$ con esa chatarra de bienes y conciencias estableció sus factorías, resultante de la revolución capitalista en las postrimerías del siglo pasado. Sus líneas de avance no encuentran obstáculos infranqueables. Asociado su poderío al de las instituciones republicanas, el estatismo estableció sus tentáculos sobre el individuo, que no halló un medio de defensa adecuado para enfrentarse a tamaño poder. Se trata de una experiencia de contornos universales, no desdeñable para el estudio de las corrientes históricas del pensamiento humano.

La constitución de pequeños estados individuales dentro del complejo de las naciones, vino a suceder a los Estados patriarcales del medievo. Su potencialidad dió vigor funcional al mecanismo de la economía moderna y autoridad ilimitada en el aspecto jurídico de las naciones, creando un clima represivo de carácter social y dió nacimiento a los nacionalismos virulentos que con voracidad feroz arrollaron en los últimos tiempos los baluartes de la conciencia, con miras a la mejor explotación de la energía humana en pos de una mano de obra más barata. La oposición a esa fuerza ciega, que desconoce sentimientos y para la cual los ojos no derraman lágrimas, no se hizo esperar, como un resultado natural de violencia individual, desembocando en los grandes movimientos colectivos que torcieron el curso ordinario de la historia, poniendo en libertad de movimientos las reservas espirituales.

Como vemos, el fenómeno se repite sin intermitencias. A un acontecimiento económico o religioso, por asociación de ideas, se le agrega otro de tipo social. Conceptos que el individuo sostenía como principio histórico, se derrumban con facilidad vertical, al tropezar con una verdad que tomamos por indiscutible, pero que, establecida, se convierte ya en rémora por impulso de inconformidad. Así fueron desgajándose las dinastías, los imperios y las naciones. Las causas aparentes fueron distintas; pero las reales tienen un motivo uniforme que es la inestabilidad del tiempo y las cosas, regidos por múltiples factores de diverso orden funcional del espíritu humano. En poco más de treinta siglos, el hombre vió agotarse civilizaciones y contribuyó al establecimiento de nuevas formas de vida, de nuevos cultos y estados de conciencia. Así en el orden económico, como 
en el religioso o social, renunció a sistemas considerados anticuados, para crear otros acordes con su estado espiritual. En el terreno puramente intelectual, renunció a escuelas filosóficas, poéticas y literarias, para acomodar sus especulaciones conforme con su estado de comprensión.

Hasta aquí sabemos lo que fuimos. Trazando una curva, partimos de los albores de la civilización antigua, para llegar a este siglo del industrialismo, donde la máquina regula los movimientos de toda la vida colectiva. Lo que seremos en el futuro está reservado a los poetas, que son visionarios y profetas del tiempo. Como siempre, son ellos los adivinadores de lo que vendrá. Dueños de los secretos del destino, por virtud de la fragilidad humana, son imprecisos y a veces inexactos, pero veraces y sinceros, porque rompen con los moldes del arcaísmo. Nos prometen un futuro y ese es innegable aunque confluyan los acontecimientos más dispares. En ese plano está colocada toda la humanidad, acosada por la fiebre inyectada por nuestra civilización industrial que abrió las válvulas del pensamiento.

Nos encontramos ubicados en la cúspide de la edad contemporánea, donde el hombre alcanzó un grado de responsabilidad que le sitúa como dueño de sus destinos. A la revolución del espíritu medieval, debemos la adquisición de una conciencia que en nosotros actúa sincrónicamente en la vida ordinaria. A la revolución capitalista de hace apenas dos siglos, somos deudores de infinidad de descubrimientos que, si bien no se operaron por interés material, constituyeron el aliciente necesario para impulsarlos. Sin redimir a ese sistema de sus crímenes, las fuerzas acumuladas para su desarrollo fueron el germen de hazañas cuya influencia revolucionó costumbres, conceptos e ideas. Negativa por su acción absorcionista la función del Estado, hubo de ser la iniciativa de pequeños grupos la que estableció leyes científicas y verdades históricas sobre cuya base se sostiene el mundo moderno.

Los grandes trasatlánticos, frente a los trirremes; los paquidermos de la guerra moderna que surcan los mares como sombras piratas, frente a la nave griega de combate; el avión, que rasga las nubes con velocidad superior a la del sonido y aun a la luz, en contraste con el sueño de Icaro; el ferrocarril, las construcciones de altos rascacielos, las comunicaciones inalámbricas que permiten 
la trasmisión de imágenes y emisiones de la voz; el desarrollo de las artes gráficas y la variedad inconmensurable de objetos de uso diverso proveniente de los plásticos, dérivados del carbono, representan en la vida moderna una realidad indiscutible de valores tangibles a la que no renuncia nuestra sensibilidad. $Y$ en punto de comparación con el desenvolvimiento del mundo de ayer, que en nuestro corto recurrido a través de la existencia apenas si cuenta cinco milenios de vida civilizada, el genio no se detiene. Si eso alcanzamos llegando aquí, i cómo cerrar los ojos a nuestro destino futuro !

De nosotros atrás queda un camino recorrido que constituye la historia de lo que fuimos. Por delante está todo lo que podremos ser, todo por realizar. En artes y ciencias, hasta aquí seguimos a tientas las lecciones de los viejos filósofos $y$ alquimistas que pretendieron elaborar la felicidad humana y obtener el oro que proporciona las riquezas materiales en el orden de las satisfacciones corporales. A simple tanteo, escudriñando en esas doctrinas, el mundo físico y moral adquirió una independencia de tal magnitud y contornos, que en el curso de los últimos dos siglos aventajó en conocimientos científicos cuanto el intelecto humano creó en toda su existencia, desde la época cuaternaria a nuestros días. Sin establecer un paralelo en cuanto a la eficacia de los descubrimientos modernos desde el punto de vista de la satisfacción moral concebida en sentido filosófico, que fué preocupación de todas las escuelas intelectuales, podemos afirmar categóricamente que es el porvenir el que nos proporcionará los bienes materiales y morales que el hombre espera desde su nacimiento. Si por cierto todo ello está condicionado a nuestra capacidad, constancia y perseverancia activas por desarrollar, es una verdad incontrastable que todo el porvenir está al alcance de las manos, si nuestro corazón responde eficientemente a los latidos de la conciencia.

En materia de arte así lo comprenden los poetas y filósofos contemporáneos. Al establecer una línea divisoria entre el pasado y el futuro, han debido aportar, al par que su espíritu crítico, la creación plástica o escrita que demostrara con elocuencia una superación de métodos con su cúmulo de sentimientos, que son las características que denuncian la obra artística. En este aspecto, ayer permanecíamos estupefactos ante los cuadros de Manet, Renoir y Cézanne. Ellos representaban lo inconexo y desconcertante de sus crea- 
ciones frente a las normas clásicas de la pintura. En la actualidad, se renueva la discusión con la pintura picassiana, resistida y confundida porque a simple vista se trata de un arte complicado y mecánico. Sus imágenes rebotan ante la vista y es necesario disponer de una gran dosis de voluntad, para comprenderlas. Como antes, también ahora rechazamos de primer intento estas novedades y nos negamos a aceptarlas. Siempre ha ocurrido así. El cubismo frente a las creaciones de un Leonardo, un Miguel Angel o un Rafael, aparece como un adefesio, sin significado evidente. No obstante, fuerza es reconocer que supone obra de arte, de un arte incomprendido, pero simbólicamente de gran contenido estético.

Referirnos a la pintura picassiana equivale a tomar un punto equidistante del arte moderno que, con sus formas, ha provocado una revolución intelectual, por romper con moldes y prejuicios sustentados como verdades inalterables que, como repetición del fenómeno operado en la técnica industrial de las ciencias mecánicas, alteraron todos los principios históricos con que el intelecto humano se ha nutrido. No sabemos a ciencia cierta a qué constelaciones nos conducirán estos conocimientos, ya que su evolución obedece al ritmo persistente $y$ continuado sin interrupciones. Sabemos que nos reservan sorpresas insospechadas, cualquiera sea el orden en que se manifesten y que los campos del arte y de las ciencias ya no tienen límites; y lo que actualmente nos parece abstracto y complicado, mañana nos resultará comprensible y asequible con claridad meridiana; que lo que aparece hoy como irreal y caprichoso, con graves defectos estéticos, puede acusar condiciones de intensa emoción si predisponemos nuestra sensibilidad para interpretarlo.

Así también en poesía nos encontramos ante un periodo revolucionario de contornos inusitados. El modernismo, interpretado como conjunto de nuevas escuelas estéticas, alcanzó su casi plena madurez, después de un ensayo de años. $Y$ un caso similar al operado en el campo de la pintura cubista lo encontramos en la poesía simbolista, uno de cuyos cultores más decididos lo representa el peruano César Vallejo, cuya estatura "sobrepasa las proporciones de la figura humana, del hombre limitado". entre su cerebro y su representación. En él encontramos la lírica de un hombre que se orienta "por los caminos de su propia sangre", huyendo del destino; que busca un equilibrio artístico de nuevas emociones estéticas en- 
tre lo pretérito y lo concreto de la vida moderna. Su poesía pertenece a él mismo, por su evasión de conducta hacia esa rebeldía que distingue a los profetas. Renunciando a las leyes de la conducta humana, a la ética social y a la moral burguesa, que "son normas impuestas al ciudadano corriente para su sanidad y su control", construyó su arte poético, obedeciendo a la libertad de los sentidos, al libre albedrío, que le proporcionaron ese singular espíritu creador.

Hombre huído del mundo, su obra carece de la acostumbrada realidad. Las imágenes, vestidas a la usanza barroca, son el resultado de una leyenda en que están envueltos el poeta y su obra, ya cargado de pesadumbre, ya con acentos sombríos o borrascosos, llevando consigo la derrota del hombre indispuesto a la lucha. No encontramos aquí al Vallejo combativo que busque en la libertad un refugio de su tristeza, en cuya evasión lo encontraremos más tarde. Más bien aparece como un representante de la decadente bohemia latina que hace poesía por el arte mismo, por mera satisfacción, sin importarle el mundo material y egoísta que salpicó la obra de sus primeros tiempos. Producto mestizo de una raza que encierra la rebeldía de su alma atormentada en el sentimiento, renunciando al combate abierto que constituye el motivo principal de la defensa por la vida, se concentra en sí mismo, como una coraza, y espera. $Y$ en vez de afrontar todas las consecuencias derivadas de una acción que en movimiento el vigor de sus articulaciones y la capacidad de creación, se adormece en la angustia y en el dolor que lleva a sus espaldas como una pesada carga.

En este estado anímico en que está sumergido, Vallejo hace ostentación individual de disponer de su libertad, sin interesarle cuanto le rodea, igual que si su existencia le perteneciera como ejemplar único de la creación y no tuviera que rendir cuentas a ningún poder natural, de sus actos. En esa rebeldía pasiva quema brutalmente y a capricho los restos de sus energías debilitadas, como un reto a la sociedad dentro de la que gime y padece, cuya conducta le es indiferente, hostil y aborrecible, cual si todos los dolores y pesares de la humanidad se desplomaran sobre su alma enfermiza $\mathrm{y}$ entristecida.

Sin lograr hurtarse a ésa preocupación, prosigue la ruta de los poetas gemebundos, acaparadores de llantos y lamentos. De ahí que su poesía sea el producto de una escuela ya olvidada, que en el 
siglo pasado $\mathrm{y}$ hasta principios del presente marchitó tanta rosa creada para la alegría y la virtud. Para colmo de desdichas, en este estado soporífero del que saldría poco después, el poeta da con sus huesos en la cárcel, acusado de incendiario, elemento subversivo, enemigo de la sociedad, echando sobre él todos los epítetos que el lenguaje criollo aplica a los disconformes y a los rebeldes. Sus tres primeros libros son la expresión cabal de una raza indígena condenada "por la conquista a dolor incesante" y en ellos construye la poesía de "varias generaciones que no habían hallado durante siglos y que, con este hombre flaco y solitario, decían su primera voz de lamentaciones y blasfemias". Tanto en Trilce como en Los heraldos negros hay la amargura andina vuelta piedra "y roca en sus cordilleras vertebradas, con sus indios vueltos piedra también, de donde puede salir y alumbrar algún día, definitivamente, su sangre como una antorcha derramada". Aquí se agranda su personalidad con legítima voz pertana que tradujo el paisaje del hombre en un lenguaje poético con expresiones propias de aquello que conocemos como de procedencia criolla. En gráficos giros personales, debajo de su piel seca y oscura, de su triste hermetismo, arde en este producto autóctono la silenciosa rebeldía del indio contra el conquistador y los conquistadores de la tierra y sus riquezas. Su protesta no resuena por lo negativa, puesto que no es enfocada con sentido de liberación, sino simplemente como hecho de existencia, de permanencia, en el reencuentro del mundó ideal que los cielos reservaron para el sindicato de profetas santificados. La más grande virtud que acusa, reside en la disconformidad, en el desprendimiento de convencionalismos y modalidades, si bien con ese fondo insondable del escepticismo melancólicamente fatalista, similar a "esos golpes sangrientos" y a las "crepitaciones de algún pan que en la puerta del horno se nos quema", que la empañan y restan forma, bríos y color. La privación de la libertad de este hombre angustiado, le coloca en el cruce de dos caminos y decide huir del país, del continente, porque no podía hacerlo para otro planeta. Esa expatriación le permitió encontrar el camino de la libertad.

Luto y llantos, albores de crueldad, canturreo de místicos bronces, funerales de lúgubres vinos, rumores de crespón ante "fríos óleos de luna muriente en blanco panteón de cautiverio, mientras los años van curvando como guadañas su ruta veloz" y arrastra al 
fondo del abismo el festín de rosas que la naturaleza delicadamente creó para adorno de la alegría y el candor universales; el deseo de dormir eternamente a la sombra de "nuestros labios difuntos", de un "convite heroico de luceros", quebrados en "el mortero de cosas de este mundo", dejaron su camino recorrido y allí se quedaron en el tiempo olvidado. Quien prosigue la ruta aquí truncada es otro poeta que, sintiendo la necesidad de marchar al compás de su tiempo, se esfuerza por abandonar el marco expresivo de su poesía. Antes había pretendido representar una generación literaria vacía de ideas, que se expresaba en un lenguaje cabalístico. Ahora, identificado con el ambiente europeo, en el que profundizó sus raíces, se hunde en el hombre y en su futuro humano. $Y$ caprichoso $y$ extraño, juega con los ritmos y las formas en versos asimétricos y asonantes. Si emplea nebulosas imágenes, como la "tarde cocinera" que "se detiene ante la mesa donde tú comiste, y muerta de hambre tu memoria viene sin probar ni agua, de lo puro triste", en cambio se presenta enérgico y contumaz, retando a su arte y a su generación que va de "crepúsculo en crepúsculo, vibrando ante la caja sonora de una herida que a vosotros no os duele", que "os transfiguráis y, creyendo morir, percibís la sexta cuerda que ya no es vuestra". Así justifica en los Poemas humanos su última voluntad poética, que "no tiene antecedentes, ni tiene pasado". El poeta está "muriéndose y tiene urgencia en cumplir con una tarea impuesta", naciendo a la poesía en un mensaje angustioso que desea entregar a los hombres.

Aquí se define César Vallejo en toda su grandiosidad, como adelantado y precursor, no conociendo la literatura moderna "una similar capacidad de ese dolor, esa angustia que no es la falsa y metafísica del flamante existencialismo, últimamente explotada con hiriente espíritu utilitario" y totalitario, como afirma Adoum. E1 mensaje del poeta está en él y constituye uno de los rasgos más netos y claros del indigenismo, como producto orgánico y espontáneo ajeno a la nostalgia literaria de los pasadistas, trasladado a la conciencia universal. Probablemente no sea fácil comprender en toda su intensidad esta poesía "que no está al alcance de todo el mundo por lo desconcertante y subjetiva", como el arte de Picasso; pero testimonia al hombre en su paso por la tierra como agente y elemento creador, que lleva al poema los elementos del suelo en 
que nació "y las expresiones de su pueblo", interponiéndose ante la gloria inmarcesible de González Prada y Rubén Dario, si en otros metros y rimas, con ese mismo fervor de universalidad.

" ¡Hasta cuándo estaremos esperando lo que no se nos debe! ¡Y en qué recodo estiraremos nuestra pobre rodilla para siempre! ¡Hasta cuándo la cruz que nos alienta no detendrá sus remos! ; Hasta cuándo la duda nos brindará blasones por haber padecido! Ya nos hemos sentado mucho a la mesa, con la amargura de un niño que a media noche, llora de hambre, desvelado. iY cuándo nos veremos como los demás, al borde de una mañana eterna, desayunados todos. ¡ Hasta cuándo este valle de lágrimas, a donde yo nunca dije que me trajeran. De codos, todo bañado en llanto, repito cabizbajo y vencido: hasta cuándo la cena durará!. Hay alguien que ha bebido mucho, y se burla, y acerca y aleja de nosotros, como negra cuchara de amarga esencia humana, la tumba"...

En tanto otros poetas pulen versos de estilo delicado, pero fríos de alma, Vallejo se ve obligado a deformar hasta el idioma, inventando "expresiones y palabras que pudieran dar una idea de to que estaba en sus huesos". "Me viene, hay días, una gana ubérrima, política, de querer, de besar al cariño en sus dos rostros, y me viene de lejos un querer demostrativo, otro querer amar, de grado o fuerza, al que me odia, al que rasga su papel al muchachito, a la que llora por el que lloraba, al rey del vino, al esclavo del agua, al que ocultóse en su ira, al que suda, al que pasa, al que sacude su persona en mi alma. Y quiero, por lo tanto, acomodarle al que me habla, su vtrenza; sus cabellos, al soldado; su luz, al grande; su grandeza, al chico, quiero ayudar al bueno a ser un poquito malo y me urge estar sentado a la diestra del zurdo, y responder al mudo, tratando de ser útil en lo que puedo, y también quiero muchísimo lavarle al cojo el pie y ayudarle a dormir al tuerto próximo".

$\mathrm{Y}$ en esos poemas desarticulados, extraños, oscuros, está la raíz de su obra futura y, pese a la "arquitectura de sus líneas, la honda raíz humana del hombre que no olvidó jamás". "Amadas sean las orejas, Sánchez, amadas las personas que se sientan amado al desconocido y su señora, al prójimo con mangas, cuello y ojos! ¡Amado es aquel que tiene chinches, el que 1leva el zapato roto bajo la lluvia, el que vela el cadáver de un pan con dos cerillas, el que se coge el dedo en una puerta, el que no tiene cumpleaños, el que per- 
dió su sombra en un incendio, el que parece un hombre, el pobre rico, el puro miserable, el pobre pobre!"

De su responsabilidad estética, él mismo diría "que hoy más que nunca quizás sienta gravitar sobre mí una hasta ahora desconocida obligación sacratísima, de hombre y de artista: ¡la de ser libre! Si no he de ser hoy libre, no lo seré jamás. Siento que gana el arco de mi frente su más imperativa fuerza de heroicidad. Me doy en la forma más libre que puedo y ésta es mi mayor cosecha artística". Esa libertad de los Poemas humanos ha de expresarse sin mutilaciones en sus himnos a los voluntarios de la República Española, al hombre de Extremadura, a los héroes republicanos, al invierno en la batalla de Teruel y en el redoble fúnebre a los escombros de Durango que, con "España, aparta de mí ese cáliz", culmina aquí su obra y su gloria.

En la poesía de Vallejo encontramos ahora la forma dramática oculta en adormecida ternura, patéticamente dominante por su contenido humano que rebasa los límites de la austeridad porque el genio actúa de agente entre el individuo y el medio. Vallejo representa en sí mismo los dolores humanos. Su voluntad pretende adquirir la liberación de un cautiverio que le tiene aherrojado entre cadenas. Por eso resiste con fuerza ciega y en las peores condiciones, soldado en las filas del porvenir. Si su cuerpo flácido cede paulatinamente, en cambio el cerebro vuela cada vez más alto. $\mathrm{Y}$ a medida que los años transcurren, el poeta se afirma y es más dieño de su arte. En tanto el mundo se desborda en asesinatos crudelísimamente fantásticos, donde los hombres se sacrifican a millares cada día, él reacciona con violencia, asustado frente a tan pavoroso drama, con estremecimientos de agonía. Es entonces cuando comprende, y se agita y discute, atacando, ante el horizonte que se cierra y las nubes de la noche que ponen luto en las almas y lágrimas en los ojos.

De bien poco sirve el conocimiento de la historia y de todas las ciencias intelectuales, si su seca interpretación no logra hacer estallar las venas, si tenemos el alma gélida y permanecemos impasibles, en actitud negativa. Todas las investigaciones empíricas y descubrimientos de una civilización que levanta monumentos al crimen $\mathrm{v}$ abomina de las virtudes espirituales, suponen una interpretación horrorosamente nefasta, ya que ni siquiera pone amor a la justicia, 
ni ternura en el trato, ni fraternidad en el convivio. $Y$ en lugar de acercarnos al coro ideal al que desde hace tantos años los poetas y profetas pretenden en vano acercarse para entonar juntos, fervorosamente abrazados, el himno del futuro, por el contrario nos separa, nos divide y martiriza en los más variados y refinados tormentos. $Y$ no es sólo nuestro cuerpo que sufre padecimientos: no son únicamente los tejidos y tendones cortados, ni los huesos que crujen, ni las vísceras arrancadas, sino también el alma, truncada en este diluvio de horrores.

"Nos van cobrando todos el alquiler del mundo", cual si residiéramos en un planeta que no nos pertenece de igual modo que si nosotros mismos no nos perteneciéramos y la existencia constituyera una hipoteca a favor de los usureros del universo. Por eso la poesía de Vallejo, antes seca y duramente retorcida por el sufrimiento primitivo, como residuo de un instinto animal "que se deshace en un grito alegre y dolorido, casi salvaje", igual que en Miguel Hernández, se vuelve ardorosa e iracunda, en ese su estilo plomizo y apretujado, compacta y dura cual materia inerte. Es la única forma de hacer sentir el rigor del sentimiento de la palabra. Todo él denuncia, en su físico nervudo y las manos enclavijadas cual las del Nazareno, y en sus ojos profundos, auscultadores del destino y en su frente apostólica de creyente, la firmeza de la imagen y la figura. La palabra af̣luye precipitadamente y la frase es cortante y desgarradora como la de los precursores del cristianismo, de quienes parece haber heredado el ascendiente cósmico, la fe en esa religión de la poesía, que descubre los orígenes del arte y el fanatismo del creyente, de que son testimonio las líneas desesperadas de sus cejas, la figura esquelética de su cuerpo, su tez calcinada por soles y tormentas y su carácter profundamente taciturno.

El drama ibérico descubrió a Vallejo, como a Miguel Hernández y a la poesía española moderna, el camino de la tierra prometida. Allí se encontraron con los hombres que ofrendaron, voluntariamente, en holocausto de la victoria, vidas y fortunas sin medida. A las trincheras de todos los frentes afluían poetas y artesanos, pensadores y soñadores de todas las ideologías, portando los estandartes de la fe, desde los más remotos países del mundo. Jamás en la historia contemporánea se ha visto fenómeno ni mediatamente parecido. Cada uno iba guiado por la estrella de una convicción profunda, 
porque allí se cerraba el ciclo de la edad moderna. Después de España estaba el diluvio, la noche negra del prejuicio, del crimen sin causa ni reparación, de la barbarie desenfrenada que degolló tantos millones de vidas inocentes en una orgía de horror. En suelo ibérico se libraba la batalla del mundo, y comprendiéndolo así fué como aquel período congregó tal número de visionarios en sus filas combatientes. La raza, la religión, la nacionalidad quedaron fusionađas allí en un abrazo de lágrimas y de sangre.

¿Cuánta verdad encerraba aquella determinación sin paralelo, al grito de la libertad herida! Así, los "Poemas de la guerra de España" son la revelación de un hombre libre y sensible, frente a la materialización del arte y la literatura, que eternizan la obra de este escritor. El mestizo, color de bronce y perfil cortado a pico, futuro cantor del Anáhuac, de Yucatán y Potosí, de tierno y ancho corazón, pronunció en España su oración postrera: "Id e instruid a todas las gentes, y a todos se ha de lograr para la libertad de todos", queriendo con anchura y largueza, como José Martí, "a lo que tiene de más cerca, no porque lo suyo sea superior a lo ajeno ni más fino o virtuoso, sino porque el influjo del hombre se ejerce mejor y más naturalmente en aquello que conoce y de donde viene", en ese estruendo postrero de imágenes que brota de sus estrofas.

En "España, aparta de mí ese cáliz", se encueritra al "hombre en completo dominio, en equilibrio absoluto". Así como en los Poemas humanos representa el paisaje del hombre, con sus dudas, su dolor y ansiedades, en aquel libro "está la plenitud, la voz honda y cálida, la humana protesta, el corazón abierto de César Vallejo", como consigna César Miró. "Si cae España, digo, es un decir, si cae España, de la tierra para abajo, niños, icómo váis a cesar de crecer! ¡ cómo va a castigar el año al mes! ¡ cómo van a quedarse en diez los dientes, en palote el diptongo, la medalla en llanto! ¡Cómo va el corderillo a continuar atado por la pata al gran tintero! \&Cómo váis a bajar las gradas del alfabeto hasta la letra en que nació la pena! Niños, hijos de los guerreros, entre tanto, bajad la voz, que España está ahora mismo repartiendo la energía entre el reino animal, las florecillas, los cometas y los hombres. Bajad la voz, que está con su rigor, que es grande, sin saber qué hacer y está en su mano la calavera hablando y habla y habla". "Bajad la voz, os digo; bajad la voz el canto de las sílabas, el llanto de la materia 
$\mathrm{y}$ el rumor menos de las pirámides, $\mathrm{y}$ aun el de las sientes que andan con dos piedras! ¡ Bajad el aliento, si el antebrazo baja, si las férulas suenan, si es la noche, si el cielo cae en dos limbos terrestres, si hay ruido en el sonido de las puertas, si tardo, si no véis a nadie, si os asustan los lápices sin punta, si la madre España cae, digo es un decir, salid, niños del mundo; id abuscarla!..."

Rendido ante el homenaje a este pueblo, comparte entre todos y hace partícipe Vallejo de esta laudatoria oración a cuantas comunidades aspiren a la resurrección del espíritu que aquí representó. Si cae, es un decir, temblará la tierra, se detendrá el sol, no se escuchará el canto del pajarillo, ni la risa de los niños, ni sonreirán las mujeres, ni las flores abrirán su cáliz a la luz, ni la gracia áurea de la alegría endulzará los acíbares del hombre. Si cae, dijo el poeta, fusilarán al firmamento y herirán al aire y a la aurora. Y la voz del profeta ha resonado en el tiempo. Los acontecimientos demostraron cómo después de España, el luto y el llanto asolaron la tierra donde no cantó al ruiseñor y la alondra, en vano, presa del espanto, buscó un rincón donde refugiarse. Los hombres fueron sacrificados y las madres derramaron lágrimas de sangre sobre las losas de los sepulcros. Valles y montañas fueron coronados de cruces y las aldeas saltaron a pedazos calcinadas por el fuego de las explosiones.

"César Vallejo, el acento con que amas, el verbo con que escribes, el vientecillo con que oyes, sólo saben de ti por tu garganta. ¿Por qué la cuerda, para qué la cadena, si existe el hierro por sí solo? Póstrate, por eso, con indistinto orgullo, con tálamo de ornamentales áspides y exagonales ecos. ¡Restitúyete al corpóreo panal, a la beldad; aroma los floridos corchos, cierra ambas grutas al ceñudo antropoide; repara, en fin, tu antipático venado; tente pena. Que no hay cosa más densa que el odio en voz pasiva, ni más mísera ubre que el amor! Que ya no puedo andar, sino en dos harpas. Que ya no me conoces, sino porque te sigo instrumental, prolijamente. Pues el afecto que quiébrase de noche en mis bronquios, lo trajeron de día ocultos deanes $\mathrm{y}$, si amanezco pálido, es por mi obra; y si anochezco rojo, por mi obrero. Ello explica, igualmente, estos cansancios míos y estos despojos, mis famosos tíos. Ello explica, en fin, esta lágrima que brindo por la dicha de los hombres. 
iParece mentira que así tarden tus parientes, sabiendo que ando cautivo, sabiendo que yaces libre!'.

Su testamento de amor a España, dice Adoum, y a los perseguidos, es un libro en que renace la ternura del hombre y la rebeldía del indio. El poeta que tanto había cantado a la muerte, renace en esta agonía lenta mientras el mundo salta destrozado y crucificado por los que al herirlo se ampararon en el símbolo de la cruz. Ahora está mutilado, "no de un combate sino de un abrazo, no de la guerra, sino de la paz." Lo perdió todo en el curso "normal de la vida y no en un accidente", no en el orden de la naturaleza, sino en el desorden de los hombres, y este "mutilado que conozco, lleva el rostro comido por el aire inmortal e inmemorial, muerto, sobre el tronco vivo, yerto y pegado con clavos a la cabeza viva. Vi una vez un árbol darme la espalda y también un camino. Un árbol de espaldas sólo crece en los lugares donde nunca nació ni murió nadie. Un camino de espaldas sólo avanza por los lugares donde ha habido todas las muertes y ningún nacimiento. El mutilado de la paz y del amor, del abrazo y del orden y que lleva el rostro muerto sobre el tronco vivo, nació a la sombra de un árbol de espaldas y su existencia transcurre a lo largo de un camino de espaldas. De la casa del dolor parten quejas tan sordas e inefables y tan colmadas de tanta plenitud, que llorar por ellas sería poco, y sería ya mucho sonreir" .. Pero, "dejadme libre un momento para saborear esta emoción formidable, espontánea y reciente de la vida, que hoy, por primera vez me extasía y me hace dichoso hasta las lágrimas".

En el "Himnò a los Voluistarios de la República" desbordó su vaso emotivo ante el miliciano de huesos fidedignos, ctrando marcha a morir tu corazón, cuando marcha a matar con su agonía mundial", y no sabe verdaderamente dónde ponerse ni qué hacer. Corre, escribe, aplaude, llora, atisba y dice al pecho que aquel fin del mundo acabe y al bien que venga. Descubre la frente "impersonal hasta tocar el vaso de la sangre". Un día "diurno, claro, atento, fértil ioh bienio, el de los lóbregos semestres suplicantes, por el que iba la pólvora mordiéndose los codos! iOh dura pena y más duros pedernales! ¡Oh frenos los tascados por el pueblo! Un día prendió el pueblo su fósforo cautivo, oró de cólera y soberanamente pleno, circular, cerró su natalicio con manos electivas; arrastran candado ya los déspotas y en el candado, sus bacterias muertas..." i Dolores 
con rejas de esperanzas de hombres! i Miuerte y pasión de paz, las populares! "Tal en tu aliento cambian de agujas atmosféricas los vientos y de llave las tumbas en tu pecho, tu frontal elevándose a primera potencia de martirio".

$Y$ después de esta introducción laudatoria, se dirige al "proletario que mueres de universo, ien qué frenética armonía acabará tu grandeza, tu miseria, tu vorágine impelente, tu violencia metódica, tu caos teórico y práctico, tu gana dantesca, espalosísima, de amar, aunque sea a traición, a tu enemigo! Liberador ceñido de griIletes, sin cuyo esfuerzo hasta hoy continuaria sin asas la extension, vagarían acéfalos los clavos, antiguo, lento colorado el día, ¡nuestros amados cascos insepultos! ¿Campesino caído con tu verde follaje por el hombre con la inflexión social de tu meñique, con tu buey que se queda, con tu física, también con tu palabra atada a un palo y tu cielo arrendado y con la arcilla inserta en tu cansancio y la que estaba en tu uña, caminando! Constructores agrícolas, civiles y guerreros, de la activa, hormigueante eternidad: estaba escrito que vosotros haríais la luz entornando con la muerte vuestros ojos; que, a la caída cruel de vuestras bocas, vendrá en siete bandejas la abundancia, todo en el mundo será de oro súbito y el oro, fabulosos mendigos de vuestra propia secreción de sangre, y el oro mismo será entonces de oro. I Se amarán todos los hombres y comerán tomados de las puntas de vuestros pañuelos tristes y beberán en nombre de vuestras gargantas infaustas! ¡Descansarán andando al pie de esta carrera, sollozarán pensando en vuestras órbitas, venturosos serán y al son de vuestro atroz retorno, florecido, innato, ajustarán mañana sus quehaceres, sus figuras soñadas y cantadas!"

De la inmensidad universal de Vallejo bien dicen estas estrofas inimitables, inspiradas, con tanta ternura que llega hasta a la misma forma de su alma, oteando el luminoso porvenir que se espera, que promete hablar a los mudos, caminar a los tullidos, "verán ya de regreso los ciegos y palpitando escucharán los sordos. ¡Sabrán los ignorantes, ignorarán los sabios! Serán dados los besos que no pudísteis dar. ¡Sólo la muerte morirá! La hormiga traerá pedacitos de pan al elefante encadenado a su brutal delicadeza; volverán los niños abortados a nacer perfectos, especiales y trabajarán todos los hombres, engendrarán todos los hombres, comprenderán todos los hombres. Obrero, salvador, redentor nuestro, i perdónanos, herma- 
no, nuestras deudas! ¡ Combatiente que la tierra criara, armándote de polvo, calcándote de imanes positivos, vigentes tus creencias personales, distinto de carácter, intima tu férula, el cutis inmediato, andándote tu idioma por los hombros y el alma coronada de guijarros! Voluntario fajado en tu zona fría, templada o tórrída, héroes a la redonda, víctima en columna de vencedores: en España, en Madrid, es.'in llamando a matar, voluntarios de la vida. Voluntarios, por la vida, por los buenos ¡ matad a la muerte, matad a los malos! ¡ Hacedlo por la libertad de todos, del explotado y del explotador, por la paz incolora - la sospecho cuando duermo al pie de mi frente y más cuando circulo dando voces y hacedlo, voy diciendo, por el alfabeto a quien escribo, por el genio descalzo y su cordero, por los camaradas caídos, sus cenizas abrazadas al cadáver de un camino! Para que vosotros, voluntarios de España y del mundo viniérais, soñé que yo era bueno, y era para ver vuestra sangre, voluntarios... Marcha hoy de vuestra parte el bien ardiendo".

Que otros poetas expriman el gusto y sabor de la palabra, que su estrofa exalte en toda plenitud el sentimiento de la lengua, que interpreten y exalten la emoción, y que del verbo se sirvan para construir la herramienta de nuestra libertad. E1 mundo entero espera al poeta que cante a nuestro siglo, con sus revoluciones en pos de un bienestar siempre mejor; de las hazañas del hombre en artes y ciencias; de los descubrimientos que consigo trajeron aparejadas la técnica y la industria aplicadas a la producción, porque también la economía, expurgada de su fenicio cinismo, tiene su parte poética. Que ellos traigan a flor de labio cuantas esperanzas nos promete el futuro y nos digan qué seremos o cómo deberemos ser mañana, cuando la hermandad nos suelde, como fundidos en una sola persona $y$ en un mismo sentimiento. En César Vallejo encontramos cuanto podemos ser hoy como personas existentes en este momento histórico, cuando la vida se multiplica y la acción del individuo se bifurca en todos sentidos. El nos pone en contacto con la parte inmaterial, irreal a los nuestros, del presente, si evidentemente lógica mañana. Sus ojos y su alma nos descubren como elementos del porvenir. Lo que somos ahora, en este instante, para él es fugaz, pasajero, ajeno quizás. Lo que representamos pasará inadvertido y el sol proseguirá iluminando la tierra. Lo que podremos ser mañana es lo que descubrimos a través de su verso pletórico y macizo de ideas. 
Su poesía es única porque no hay ripio ni frase de relleno "ni abuso de la metáfora" y pocas veces de las imágenes. Nada extraordinario ello significa en el mundo poético; pero es que en $\mathrm{Va}$ llejo, dentro de su estilo, hay ideas claras y conceptos concluyentes. No conocemos "en nuestra lengua un caso de tal descarnadura poética, de exactitud, de rechazo a la obesidad de la palabra"... Y de ahí que no se trate de literatura, sino de una explosión emotiva que no ha sabido expresar de otra forma que en estrofas singulares, a veces descarnadas y cruelmente patéticas y otras emotivas y sentimentales, como en aquel Pedro Rojas "que nació muy niñín, mirando al cielo, y que luego creció, se puso rojo y luchó con sus células", con todas sus células del alma, "todavía sus hambres, sus pedazos. Su cadáver estaba lleno de mundo".

Con Vallejo, con su misma voz y en su propio lenguaje, digamos a coro: ¡Cuídate, España, de tu propia España! ¡Cuídate de la víctima a pesar suyo, del.verdugo a pesar suyo! ¿Cuídate del que antes de que cante el gallo, negárate tres veces; de las calaveras sin las tibias, de los nuevos poderosos, del que come tus cadáveres, del que devora muertos y vivos! Del leal ciento por ciento, del cielo más allá del aire y del aire más allá del cielo; de los que te aman, de tus héroes, de tus muertos, del futuro. $Y$ que otros poetas liberen del polvo la corona cubierta de polvo que asciende del alma y sube del fuego, le calce y dé un trono al cielo biznieto del humo y del infinito donde acaban los justos. $Y$ devuelva a la tierra, en tumulto de palmas, la medalla sin llanto y sin vientre a cuestas. Que el hierro descienda y se humille al gorrión y dé formas de hombre a falaz vanagloria. Que aviente a los bárbaros y que ciña de dioses a los átomos. Sudario del pueblo, que vas al futuro, que el corazón te guíe y te dé alas en el verde follaje de los campos. Porque de allí saldrá la luz que es sangre convertida en abundancias, sin puntas de pañuelos tristes ni el alma coronada de guijarros, ni reptiles de pestaña inmanente, ni trigos solitarios.

Campio Carpio 
